PII S0016-7037(96)00205-0

\title{
The calibration of $D[\mathrm{Sr} / \mathrm{Ca}]$ versus sea surface temperature relationship for Porites corals
}

\author{
Chuan-Chou Shen, ${ }^{1.2}$ Typhoon Lee, ${ }^{1,3}$ Chi-Yun Chen, ${ }^{1.3}$ Chung-Ho Wang, ${ }^{1}$ Chang-Feng Dal, ${ }^{4}$ and Lung-An Li ${ }^{5}$ \\ ${ }^{1}$ Institute Earth Sciences, Academia Sinica, P.O. Box 1-55, Nankang, Taipei, Taiwan, ROC \\ ${ }^{2}$ Department Chemistry, National Tsing-Hua University, Hsin-Chu, Taiwan, ROC \\ ${ }^{3}$ Department Geology, National Taiwan University, Taipei, Taiwan, ROC \\ ${ }^{4}$ Institute Oceanography, National Taiwan University, Taipei, Taiwan, ROC \\ ${ }^{5}$ Institute Statistics, Academia Sinica, Nankang, Taipei, Taiwan, ROC
}

(Received July 24, 1995; accepted in revised form June 20, 1996)

\begin{abstract}
Taking advantage of the availability of a continuous sea surface temperature (SST) record at Kenting, southern Taiwan, we have carried out a calibration of $D[\mathrm{Sr} / \mathrm{Ca}]-\mathrm{SST}$ ( $D$ : distribution coefficient) relationships for Porites lobata and $P$. lutea. Between $22^{\circ} \mathrm{C} \sim 28^{\circ} \mathrm{C}$, the best fitting linear relationships for the two species agree within their respective errors with a maximum deviation less than $0.3^{\circ} \mathrm{C}$. Our calibration overlaps with the only published calibration for Porites (deVilliers et al., 1994) but is somewhat less temperature sensitive. The maximum temperature differences for the two calibrations between $21^{\circ} \mathrm{C}$ and $27^{\circ} \mathrm{C}$ are $\pm 1.2^{\circ} \mathrm{C}$. The $D$-SST relationship calculated using the data of Beck et al. (1992, 1994) and their unpublished seawater data lies between these two calibrations. Our calibration removes some discrepancies previously described in the studies of McCulloch et al. (1994a) on the Great Barrier Reef and of Min et al. (1995) on New Caledonia. We found little growth rate effect on the calibration for $P$. lutea between $18 \mathrm{~mm} / \mathrm{yr}$ and $23 \mathrm{~mm} / \mathrm{yr}$. We have also monitored the seawater [ $\mathrm{Sr} / \mathrm{Ca}$ ] for the entire 1993. The observed variation of $0.033 \mathrm{mmol} / \mathrm{mol}$ can cause a temperature artifact of $0.7^{\circ} \mathrm{C}$ and is thus a dominant error in using this new paleo-thermometer. To carry out this experiment, we have developed a microsurgical technique that can be used to sample corals at better than $0.15 \mathrm{~mm}$ resolution. The analytical precision should ultimately allow SST reconstruction of better than $0.2^{\circ} \mathrm{C}$. Furthermore, the insensitivity of the calibration against growth rate variation and species differences suggests a promising future for this new thermometer, in contrast to the pessimism of deVilliers et al. (1995). However, inter-laboratory differences and the question of seawater [ $\mathrm{Sr} / \mathrm{Ca}$ ] variation need to be addressed first. We recommend a single SST calibration for the $\mathrm{Sr} / \mathrm{Ca}$ thermometer on coral Porites: $\mathrm{Sr} / \mathrm{Ca}_{\mathrm{N}}=10.286-0.0514 \times \mathrm{SST}(\mathrm{N}$ : normalized to Hawaii seawater $[\mathrm{Sr} / \mathrm{Ca}]=8.510 \mathrm{mmol} / \mathrm{mol})$ or $D[\mathrm{Sr} / \mathrm{Ca}]=1.2077-0.006011 \times \mathrm{SST}$.
\end{abstract}

\section{INTRODUCTION}

The best way to check the validity of climatic models is to test them against the varied conditions of our earth system in the past. Therefore, the reconstruction of paleo-climatic parameters from proxy records preserved in nature is rapidly becoming an important scientific pursuit. Potentially, highprecision [ $\mathrm{Sr} / \mathrm{Ca}$ ] concentration measurements on corals offer a superior method for estimating past sea surface temperatures (SST) with good accuracy $\left(<0.2^{\circ} \mathrm{C}\right)$ and excellent time resolution (weekly). The purpose of this paper is to present the result of our effort to calibrate this new paleothermometer.

Although the correlation between $\mathrm{Sr} / \mathrm{Ca}$ and SST was known since the 1970's (Weber, 1973; Smith et al., 1979), Beck et al. ( 1992 ) was the first to exploit the far more precise isotopic dilution mass spectrometry (IDMS) techniques. Since then, it has been applied to a number of important problems in the study of paleoclimate. These include the temperature of tropical oceans during late deglaciation time (Beck et al., 1992), last glacial maximum (Guilderson et al., 1994), last interglacial maximum (McCulloch et al., 1994b), and the strong El Niño of 1982-83 (McCulloch et al, $1994 \mathrm{a}$ ).

In spite of its great potential, there are still a number of outstanding issues that must be resolved before the $\mathrm{Sr} / \mathrm{Ca}$ method can be considered well established. Many of these have been addressed by deVilliers et al. (1994, hereafter abbreviated as dVSN). These authors noted that the magnitude of variation for seawater $\mathrm{Sr} / \mathrm{Ca}(8.5-8.7 \mathrm{mmol} / \mathrm{mol})$ corresponds to a temperature artifact of $2.5^{\circ} \mathrm{C}$. So, either the local offset between seawater $\mathrm{Sr} / \mathrm{Ca}$ has to be corrected or, equivalently, the distribution coefficient $D$ should be used instead of the concentration ratio. They further showed that $D[\mathrm{Sr} / \mathrm{Ca}]$ for coral relative to seawater is lower than that determined for inorganic precipitation of aragonite at equilibrium by Kinsman and Holland (1969). This lack of equilibrium implies that the SST- $D$ calibration may be sensitive to rate-dependent and biogenic processes. Indeed they found different temperature calibrations for corals of different genera and for samples formed at different growth rates from the same coral. Another factor requiring clarification is whether the temperature at the SST recording station can represent that of the sampling site. Yet another factor is how to extend the temperature range of the $D$-SST calibration. In fact, deVilliers et al. (1995) reported large discrepancies between corals of the same species that grew only 20 meters apart and expressed pessimism about the future of this method. Indeed, presently there exist several surprises and discrepancies when the $\mathrm{Sr} / \mathrm{Ca}$ method is applied. For in- 
stance, the temperature of the last interglacial maximum was found to be $4^{\circ} \mathrm{C}$ lower than present using corals from New Guinea (McCulloch et al., 1994b) while it was thought to be a period slightly warmer than the present. Moreover, the SST of tropical Pacific (Vanuatu, Beck et al., 1992) $10 \mathrm{kyr}$ ago was $4^{\circ} \mathrm{C}$ lower than that at tropic Atlantic (Barbados, Guilderson et al., 1994) at the same time. The difference is much larger than expected. Careful investigation of possible pitfalls of the new method may help to settle some of these key questions.

This paper is a report of our effort to calibrate the $D$-SST relationship for the two widely sampled species, $P$. lobata and $P$. lutea. We took advantage of the availability of continuous SST recording at the water intake of a nuclear power plant located at Kenting, southern Taiwan, since 1987. Our calibration is then compared with the only other such calibration in the literature (dVSN). We further investigated the growth rate effect and the variation in seawater [ $\mathrm{Sr} / \mathrm{Ca}$ ]. A preliminary report of our result was presented by Lee et al. (1995).

\section{SAMPLE TREATMENT AND MEASUREMENT METHODS}

Coral species of $P$. lobata and $P$. lutea were gathered on January 1, 1993 and 1994, respectively, at the water intake of the Third Nuclear Power Plant, Nanwan Bay, Kenting National Park, southern Taiwan, at depths of $2 \mathrm{~m}$ and $4 \mathrm{~m}$, respectively (Fig. 1). There is no temperature difference between these two depths as measured by means of highly accurate $\left(0.05^{\circ} \mathrm{C}\right)$ thermometers. Sea surface water samples were collected monthly from Jan., 1993 to Dec., 1993 from the same site. Corals were sectioned along the vertical direction of growth into $1.0 \mathrm{~cm}$ thick slices using a diamond-band saw. They were immersed in $10 \%$ sodium hyperchlorite for at least one day to get rid of organic matrix materials, then washed with deionized water in an ultrasonic cleaner and finally dried at $50^{\circ} \mathrm{C}$ in an oven. Growth rates were about $15-16 \mathrm{~mm} / \mathrm{yr}$ for $P$. lobata and $17-23$ $\mathrm{mm} / \mathrm{yr}$ for $P$. lutea as estimated from density bands on X-ray photographs.

On each slice, subsamples of $P$. lobata, each weighing about $5-$ $6 \mathrm{mg}$, were drilled with a drill bit of $1 \mathrm{~mm}$ in diameter at a fixed interval of $1.5 \mathrm{~mm}$ along the axis of maximum growth and crushed into fine powder in an agate mortar (circular holes in Fig. 2). An improved sampling technique was applied to $P$. lutea. Using a micrometer-controlled 3-D stage and a high speed $(7,500-25,000 \mathrm{rpm})$ fine (thickness $0.15 \mathrm{~mm}$ ) circular diamond saw, we first cut two parallel lines $1.5 \mathrm{~mm}$ apart along the maximum growth direction. Further cutting then produced small sample cubes $(1.5 \times 1.5 \times 2$ $\mathrm{mm}^{3}$ ) (Fig. 2). All cutting was performed with methanol as a coolant. The technique can obviously be used for higher resolution sampling as small as $0.15 \mathrm{~mm}$ intervals, if necessary. The cubes were crushed and homogenized in a mortar. Most of the samples were used for carbon and oxygen isotopic analysis. A small aliquot of the coral sample powder, about $50 \mu \mathrm{g}$ in weight, was weighed using a micro-balance and dissolved in a drop of $1 \mathrm{~N} \mathrm{HCl}$. Optimal amount of ${ }^{42} \mathrm{Ca}-{ }^{44} \mathrm{Ca}-{ }^{84} \mathrm{Sr}$ triple spike solution was added so that the ${ }^{42} \mathrm{Ca}$ from spike was twenty-five times that from sample. We then directly loaded about $1 / 20$ of the mixture solution on a single Ta filament. The MAT-262 at IES was used to measure first calcium then strontium isotopic ratios. In order to remove instrumental mass fraction-

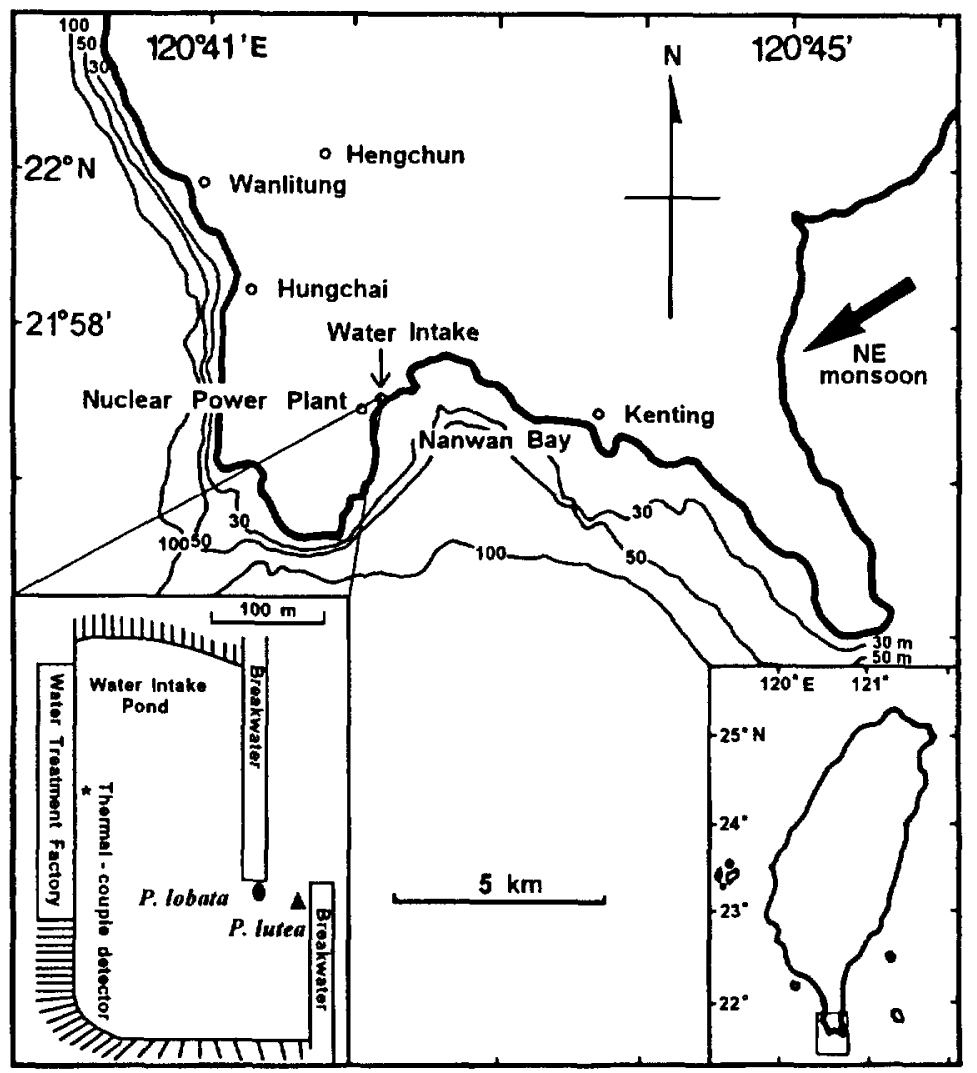

FIG. 1. Nanwan Bay in Kenting National Park, southern Taiwan. Coral and seawater samples were collected at the water intake pond of the Third Nuclear Power Plant, where continuous SST measurements have been taken since 1987. The distance between the thermal-couple sensor used to measure SST and the coral sampling site is about $200 \mathrm{~m}$ 


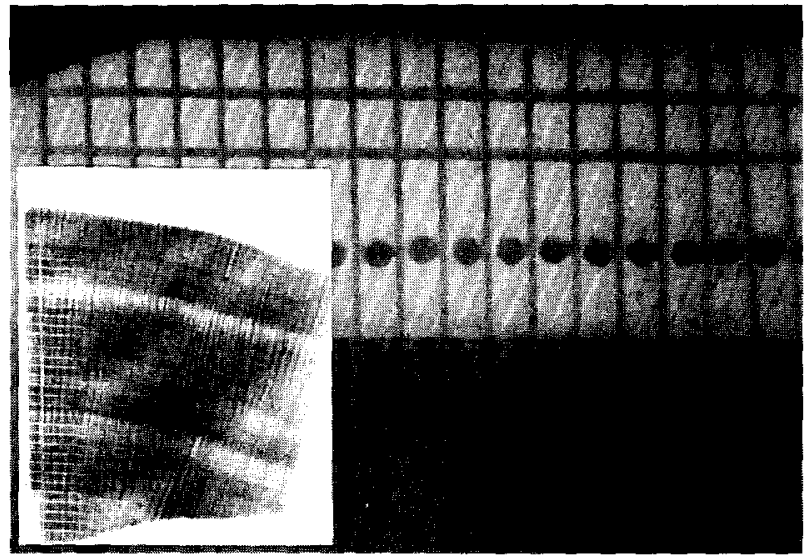

FIG. 2. Enlarged photograph and X-ray photograph (inset) of Porites coral slab subsampled using a $1.0 \mathrm{~mm}$ drill (circular holes) and with a $0.15 \mathrm{~mm}$ thick diamond saw (thin cuts). The microsurgical stage plus the ultra-small diamond saw developed offer a well controlled micro-sampling capability. Since $0.15 \mathrm{~mm}$ is equivalent to about three day worth of coral growth, better than weekly resolution is achievable. This method seems to have some advantages over the drill method.

ation in thermal ionization mass spectrometry, single spike isotopic result of $\mathrm{Sr}$ was normalized to ${ }^{86} \mathrm{Sr} /{ }^{88} \mathrm{Sr}=0.1194$ while the double spike $\mathrm{Ca}$ results were corrected to ${ }^{42} \mathrm{Ca} /{ }^{44} \mathrm{Ca}=0.29969$.

Typically $\mathrm{l}-2 \mathrm{mg}$ coral subsamples were measured for oxygen isotopic analysis on a MAT252 mass spectrometer with an external precision of $0.10 \%,(2 \sigma)$ and $\delta^{18} \mathrm{O}$ values are expressed relative to the PDB standard.

Monthly samples of seawater of 1993 were also subject to $\mathrm{Sr}, \mathrm{Ca}$, and $\delta^{18} \mathrm{O}$ analyses. First, $50 \mathrm{c.c}$. samples were filtered by membrane filters (MFS $0.45 \mu \mathrm{m}$ ). Subsequently, a $0.05 \mathrm{~g}$ aliquot was mixed with suitable amount of triple spike and eluded through a cationexchange resin column (Biorad AG-50W $\times 8,100-200$ mesh) to remove other sea salts. This was followed by the collection of $\mathrm{Sr}$ and $\mathrm{Ca}$ together in one fraction. They were measured in mass spectrometers the same way as coral samples.

Daily mean temperatures were obtained by averaging three readings: the maximum and minimum readings from the continuous thermal couple trace on the chart recorder plus one reading taken manually at 8:00 a.m. everyday. Temperature difference between the sampling site and the continuous recording thermal couple sensor location, where long-term SSTs record was obtained, was checked by simultaneous measurements with high precision calibrated mercury thermometers $\left( \pm 0.05^{\circ} \mathrm{C}\right)$ whose calibration is traceable to the absolute national temperature standard.

\section{TEST OF THE ISOTOPE DILUTION METHODS}

A long duration data acquisition run for $\mathrm{Ca}$ on MAT262 was performed to ensure that unusually large mass fractionation effects can be efficiently corrected using our double spike method (Fig. 3). The raw ${ }^{46} \mathrm{Ca} /{ }^{42} \mathrm{Ca}$ ratios were severely fractionated by as much as $26 \%$. The corrected ratios spanned a range only $0.6 \%$ and the mean value converged to a $2 \times \mathrm{S}$. D. $\leqq+0.035 \%$ by using exponential law (Russell et al., 1978). It is also obvious from Fig. 3 that the linear law did not completely remove the fractionation effect.

For $\mathrm{Sr} / \mathrm{Ca}$ ratio, a long-term reproducibility of $\pm 0.44 \%$ o $(2 \sigma, n$ $=7$ ) was achieved as demonstrated by repeated analyses of the same coral sample powder. The external error of repeated measurements of the same seawater sample was $\pm 0.55 \%(2 \sigma, n=3)$.

\section{RESULTS AND DISCUSSION}

\subsection{Temperature Differences between the Sampling} Site and the SST Recording Sensor Location

Ideally, when calibrating the $\mathrm{Sr} / \mathrm{Ca}$-SST relationship, one should use continuous SST record at the coral site after appropriately averaging over time periods when the sample growth actually took place. This has not been the case for most of the published work. Beck et al. (1992) used $\delta^{18} \mathrm{O}$ to infer the temperature. dVSN's measurement at Galapagos is based on SST $100 \mathrm{~km}$ away. Only at Hawaii (KoKo Head, Oahu) was weekly bucket measurements made near the sampling site.

To overcome this difficulty, we first calibrated both the continuous SST sensor reading and a CTD against our absolute mercury thermometer. We then monitored the temperature difference between the sensor location and the sampling site $200 \mathrm{~m}$ away as recorded by the CTD over a $48 \mathrm{~h}$ period. During that time the SST variation was less than $1^{\circ} \mathrm{C}$. Figure 4 shows the result. Instantaneous differences varied between $-0.4^{\circ} \mathrm{C}$ and $0.7^{\circ} \mathrm{C}$ and were probably attributable to the change of water depth at coral site with tide and direct heating of the shallow sea bottom by the solar insolation. However, the difference averaged over $24 \mathrm{~h}$ was only $0.15^{\circ} \mathrm{C}$. We thus believe that temperature difference averaged over time longer than a week was probably at most $0.1^{\circ} \mathrm{C}$. The use of the continuous SST record should be accurate to this level.

\subsection{Temporal Sr/Ca Variability of Sea Surface Water}

The conventional practice to separate liquid and particulate phases in aquatic chemistry is by filtration with 0.45 $\mu \mathrm{m}$ membrane (Goldberg et al., 1952). But this has been challenged by recent works (Dai et al., 1995; Baskaran and

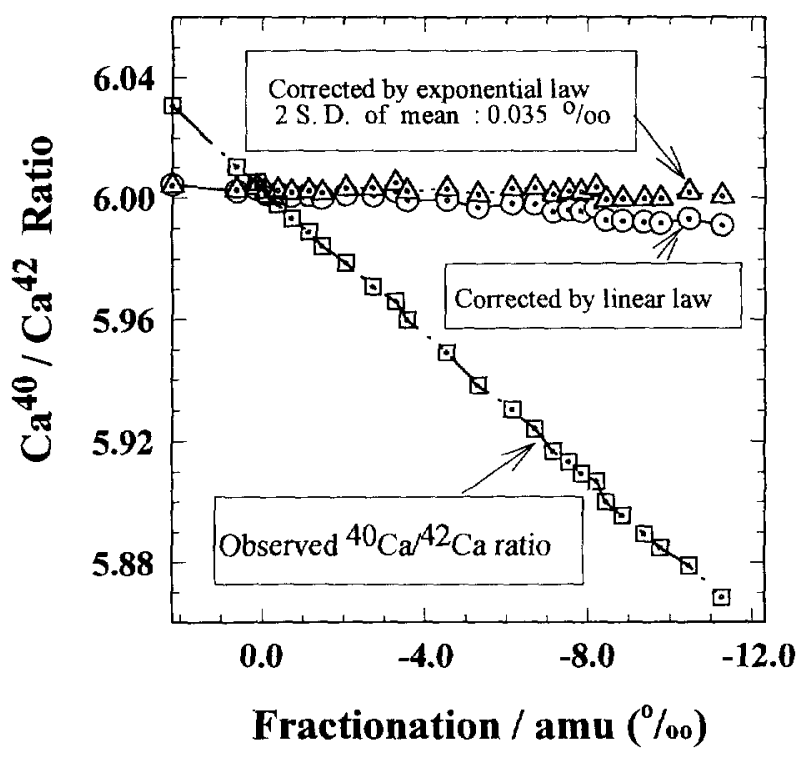

FIG. $3 .{ }^{40} \mathrm{Ca} /{ }^{42} \mathrm{Ca}$ ratio vs. mass fractionation factor per amu of mass differences (negative favoring heavy isotopes). An extremely fractionated thermal ionization mass spectrometer run of a sample spiked at a ratio of ${ }^{42} \mathrm{Ca}_{\text {spike }}:{ }^{42} \mathrm{Ca}$ coral $=25: 1$. It demonstrates that our 42-44 double spike procedure can correct for the fractionation effect up to $26 \%$ in $42 / 40$ so that it converges to a $2 \times$ S.D. of the mean $= \pm 0.035 \%$. The $95 \%$ confidence level for our run to run reproducibility in $\mathrm{Sr} / \mathrm{Ca}$ using the triple spike method was $0.44 \%$ o based on seven separately spiked aliquots of the same sample powder. 


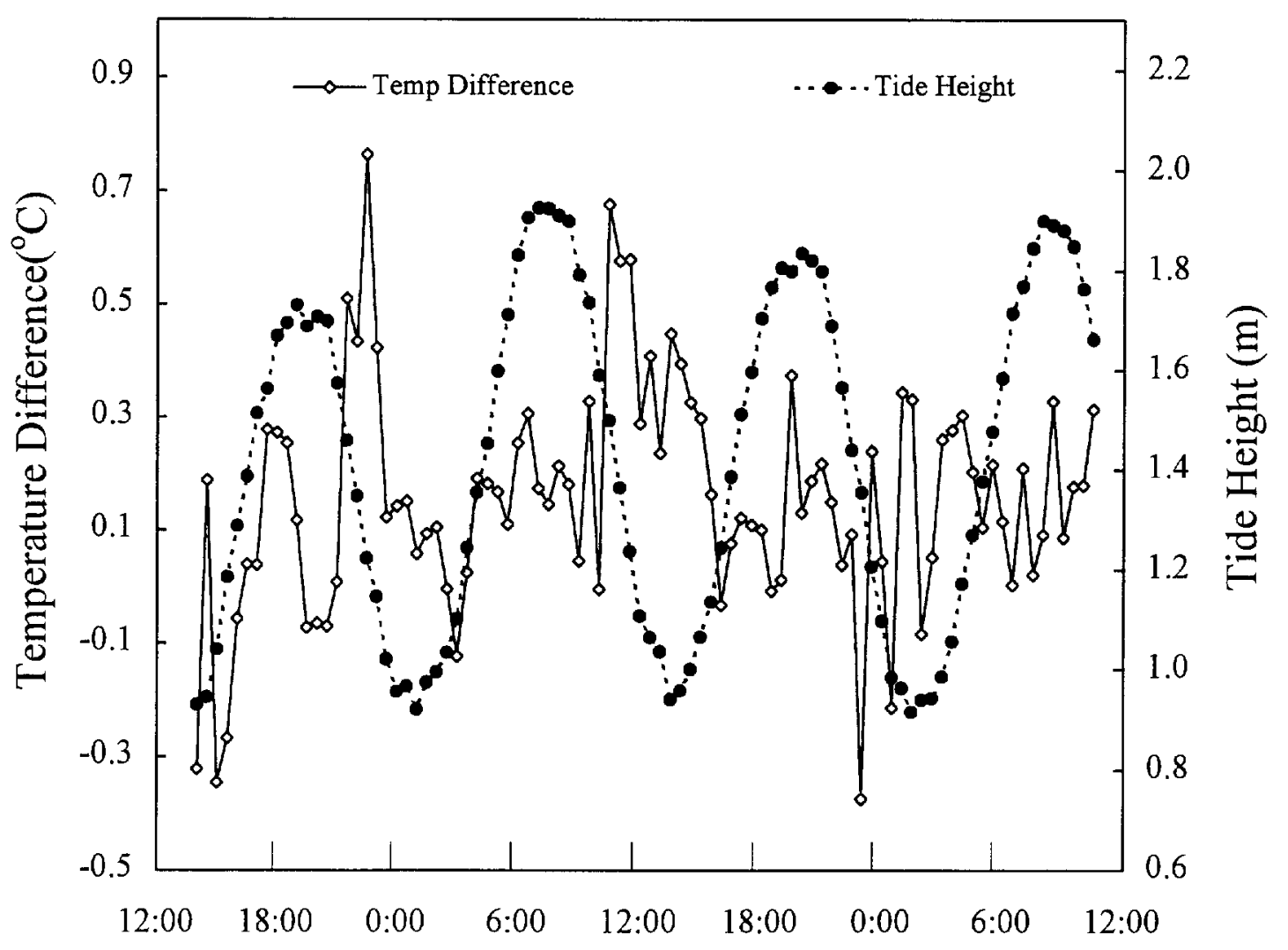

$$
12: 009 / 6 \sim 12: 009 / 8,1994
$$

FIG. 4. Diurnal fluctuation of temperature differences between the sampling site and the thermal couple recorder location for long time SSTs measurements. Temperature differences of up to $0.7^{\circ} \mathrm{C}$ were found over short timescale (hour). However, the 24 hour average difference was less than $0.15^{\circ} \mathrm{C}$, between the two locations. Tidal heights are also plotted.

Santschi, 1993; Martin et al., 1995). It is not clear how should one filter the water sample such that it best represents the seawater from which coral extracts the Sr and Ca. dVSN found no significant difference between filtered $(0.45 \mu \mathrm{m})$ and unfiltered seawater samples of open ocean in the central North Pacific Ocean. However, this is not necessarily applicable to the coastal water in the semi-enclosed Nanwan Bay. As an exploratory test, we divided our November seawater sample into three portions, one unfiltered, the other two filtered using $5 \mu \mathrm{m}$ and $0.45 \mu \mathrm{m}$ filters, respectively. As shown in Table la, the $\mathrm{Sr} / \mathrm{Ca}$ ratio of unfiltered one is only 0.0057 $\mathrm{mmol} / \mathrm{mol}$ higher than the one filtered by $0.45 \mu \mathrm{m}$ membrane. This result is similar to dVSN's. But the one filtered by $5 \mu \mathrm{m}$ membrane showed a $\mathrm{Sr} / \mathrm{Ca} 0.030 \mathrm{mmol} / \mathrm{mol}$ higher than those filtered by $0.45 \mu \mathrm{m}$ membrane. Similar offsets were also found in three other samples. This phenomenon suggests that particulates between $0.45-5 \mu \mathrm{m}$ possess higher $\mathrm{Sr} / \mathrm{Ca}$ ratios. Using the measured Ca concentrations for the three fractions of the 11/6 sample, we can infer the $\mathrm{Sr} / \mathrm{Ca}$ of the three components that contributed to the seawater $\mathrm{Ca}$ and $\mathrm{Sr}$ at Kenting in Table $1 \mathrm{~b}$. It is also conceivable that the blank in $5 \mu \mathrm{m}$ filters may contribute to the high $\mathrm{Sr} / \mathrm{Ca}$ for that fraction. To conform to the usual convention, we still decided to pass all of our seawater samples through 0.45 $\mu \mathrm{m}$ filters before measurements. Whether this is the correct procedure should be a subject for further study.

The average $\mathrm{Sr} / \mathrm{Ca}$ ratio of seawater samples for 1993 at our sampling site is $8.551 \mathrm{mmol} / \mathrm{mol}$ (Fig. 5a, Table 2) well within the worldwide range of $8.5116-8.5855 \mathrm{mmol} / \mathrm{mol}$ as compiled by dVSN. We will use this value to represent the seawater value in the distribution coefficient calculation below. However, the total range of seawater $\mathrm{Sr} / \mathrm{Ca}$ was $8.539-8.572 \mathrm{mmol} / \mathrm{mol}$. This range of $0.033 \mathrm{mmol} / \mathrm{mol} \mathrm{cor}-$ responds to a temperature artifact of $0.7^{\circ} \mathrm{C}$. The existence and magnitude of such temporal variations should be the subject of careful further investigation. This will be necessary before the high precision and time resolution of this new powerful thermometer can be fully exploited. Furthermore, how different the seawater [ $\mathrm{Sr} / \mathrm{Ca}$ ] was during glacial and the last interglacial remains an important yet open question. Sea surface $\mathrm{Sr} / \mathrm{Ca}$ ratio of November, $8.572 \mathrm{mmol} /$ mol, is higher than the ratios of other months, 8.539-8.560 


\begin{tabular}{cccccc}
\hline Date & $8 / 31 / 93$ & $9 / 28 / 93$ & $12 / 10 / 93$ & $11 / 6 / 93$ & {$[\mathrm{Ca}] \mu \mathrm{mol} / \mathrm{g}$} \\
\hline No filtration & & & & 8.5780 & 10.332 \\
$5 \mu \mathrm{m}$ & 8.5635 & 8.5749 & 8.6110 & 8.6030 & 10.030 \\
$0.45 \mu \mathrm{m}$ & 8.5413 & 8.5513 & 8.5421 & 8.5723 & 9.626 \\
\hline
\end{tabular}

\begin{tabular}{cccc}
\hline & {$[\mathrm{Ca}] \mu \mathrm{mol} / \mathrm{g}$} & Percent $\%$ & $\mathrm{Sr} / \mathrm{Ca}$ mmol/mol \\
\hline$<0.45 \mu \mathrm{m}$ & 9.626 & 93 & 8.572 \\
$0.45 \sim 5 \mu \mathrm{m}$ & 0.406 & 4 & 9.317 \\
$>5 \mu \mathrm{m}$ & 0.302 & 3 & 7.776 \\
\hline
\end{tabular}

a. $2 \sigma$ reproducibility $= \pm 0.0047 \mathrm{mmol} / \mathrm{mol}$ as determined by three separately spiked samples for the same seawater

a. Calculated from 11/6 data in Table 1a.

$\mathrm{mmol} / \mathrm{mol}$. This may possibly be the consequence of the intrusion of deep water masses brought up by the Kuroshio and the current from the South China Sea. Their high salinity and high nutrient (Shaw, 1989) can increase Sr/Ca which correlates with nutrient according to dVSN. Alternatively, it may be a local runoff effect. A water sample collected from a local stream nearby has a high $\mathrm{Sr} / \mathrm{Ca}$ of $8.833 \mathrm{mmol} / \mathrm{mol}$. This is expected as the entire area was covered by raised coral reefs which release $\mathrm{Sr}$ preferentially when they are altered by interacting with fresh water.

Similar problems are well known in oxygen isotope thermometry. At Nanwan Bay, because of the heavy seasonal rain in the summer and early autumn (Fig. 5b), there is an offset in $\delta^{18} \mathrm{O}$ of $0.18 \%$ between the July to January values and the February to June values. The annual $\delta^{18} \mathrm{O}_{\mathrm{PDB}}$ range of $0.24 \%$ ( $2 \times$ S.D. $)$ also corresponds to a temperature shift of more than $1^{\circ} \mathrm{C}$ temperature difference. A comparison between $\mathrm{Sr} / \mathrm{Ca}$ ratio and $\delta^{18} \mathrm{O}_{\mathrm{POB}}$ of $P$. lutea suggests that there may be a $\delta^{18} \mathrm{O}$ anomaly of $\sim 0.4 \% 0\left(\sim+1.5^{\circ} \mathrm{C}\right)$ in the summer of 1991, possibly because of the more intense precipitation of that season (Fig. $5 \mathrm{c}$ ).

\subsection{The Sr/Ca-SST Relationship for Porites Corals}

The Sr/Ca-SST relationship was established using the data for January 1989 to January 1991. We converted the sampling positions to time periods by assuming that the winter and summer temperature extremes correspond to the extreme $\mathrm{Sr} / \mathrm{Ca}$ ratios. In between the five extremes constant growth rates were assumed. For $P$. lobata, we found that the growth rates for these four periods are all about $15-16 \mathrm{~mm} /$ yr (Fig. 6a). For P. lutea, the growth rates throughout 1989 were about $18 \mathrm{~mm} / \mathrm{yr}$ while from January to August of 1990 it grew at a rate of almost $20 \mathrm{~mm} / \mathrm{yr}$ and then accelerated to $23 \mathrm{~mm} / \mathrm{yr}$ between August 1990 and January 1991 (Fig. 6b). Linear least square regression minimizing the deviation in $\mathrm{Sr} / \mathrm{Ca}$ gave the following relationships between skeletal $\mathrm{Sr} / \mathrm{Ca}$ and SST (Fig. 6c):

$$
\begin{gathered}
\mathrm{Sr} / \mathrm{Ca}(\mathrm{mmol} / \mathrm{mol})=10.307-0.0505 \times \mathrm{SST}\left({ }^{\circ} \mathrm{C}\right) \\
R^{2}=0.91 \text { for } P . \text { lutea } \\
\mathrm{Sr} / \mathrm{Ca}(\mathrm{mmol} / \mathrm{mol})=10.356-0.0528 \times \mathrm{SST}\left({ }^{\circ} \mathrm{C}\right) \\
R^{2}=0.96 \text { for } P . \text { lobata. }
\end{gathered}
$$

The 95\% confidence envelope of Eqn. 1, calculated using the regression method of Draper and Smith (1980), indicates that SST can be inferred from $\mathrm{Sr} / \mathrm{Ca}$ measurements using this calibration to about $\pm 0.2^{\circ} \mathrm{C}$. This is close to what analyt- ical uncertainty of $0.44 \%$ in $\mathrm{Sr} / \mathrm{Ca}$ alone can account for $\left(\sim 0.1^{\circ} \mathrm{C}\right)$.

\subsection{Intragenus Variation}

The sensitivity of $\mathrm{Sr} / \mathrm{Ca}$ ratio uptake changed by SST is $0.0505 \mathrm{mmol} / \mathrm{mol} /{ }^{\circ} \mathrm{C}$ for $P$. lutea and $0.0528 \mathrm{mmol} / \mathrm{mol} /$ ${ }^{\circ} \mathrm{C}$ for $P$. lobata. The two $\mathrm{Sr} / \mathrm{Ca}$-SST relationships are not significantly different at $95 \%$ confidence interval. Compared to $P$. lobata, the $P$. lutea relation gives the same temperature in winter but slightly warmer temperature in summer by only $0.2-0.3^{\circ} \mathrm{C}$ (Fig. $6 \mathrm{c}$ ). Since the growth rates probably were not constant between extremes, we are currently investigating the effect of using different assumptions on the growth rate model (e.g., cosine function, Taylor et al., 1993) on the calibration relations. Furthermore, since coral $\mathrm{Sr} / \mathrm{Ca}$ ratios are out of equilibrium, presumably driven by biological kinetic effects, it will be prudent to check whether even distinct coral heads of the same species can display different kinetic effects as claimed by de Villiers et al. (1995). This check is in progress.

\subsection{The Growth Rate Effect on Skeletal $\mathrm{Sr} / \mathrm{Ca}$}

The difference of $\mathrm{Sr} / \mathrm{Ca}$ uptake between the faster and slower growth rate for Pavona clavus, a columnar coral, is significant ( $d V S N$ ). The slower the growth rate is, the closer the $D$ value approaches the equilibrium value of inorganic aragonite. They found this growth rate effect by comparing samples grown along a fast axis at $11-12 \mathrm{~mm} / \mathrm{yr}$ and those grown along a slow axis at $4-7 \mathrm{~mm} / \mathrm{yr}$.

The different growth rates of $P$. lutea in the different periods that we studied provide an opportunity to check for growth rate effects. Separate $\mathrm{Sr} / \mathrm{Ca}-\mathrm{SST}$ relationships are constructed for summer to winter of 1989 and 1990, respectively (Fig. 6d). The growth rates of these two periods were $18 \mathrm{~mm} / \mathrm{yr}$ and $23 \mathrm{~mm} / \mathrm{yr}$, respectively, a difference of $28 \%$. The difference between these two relationships is less than $0.1^{\circ} \mathrm{C}$ and they are indistinguishable at $95 \%$ confidence interval. This result, when combined with the $P$. lobata result, suggests that a single $\mathrm{Sr} / \mathrm{Ca}$-SST relationship can be used for Porites sp. whose growth rates vary between 15 and 23 $\mathrm{mm} / \mathrm{yr}$.

\subsection{Comparison between $D[\mathrm{Sr} / \mathrm{Ca}]-S S T$ Calibrations}

The various $\mathrm{Sr} / \mathrm{Ca}$ vs. SST relationships are not directly comparable because seawater $\mathrm{Sr} / \mathrm{Ca}$ differences would offset them (Fig. 7a). Since different water masses may have their 
(a)
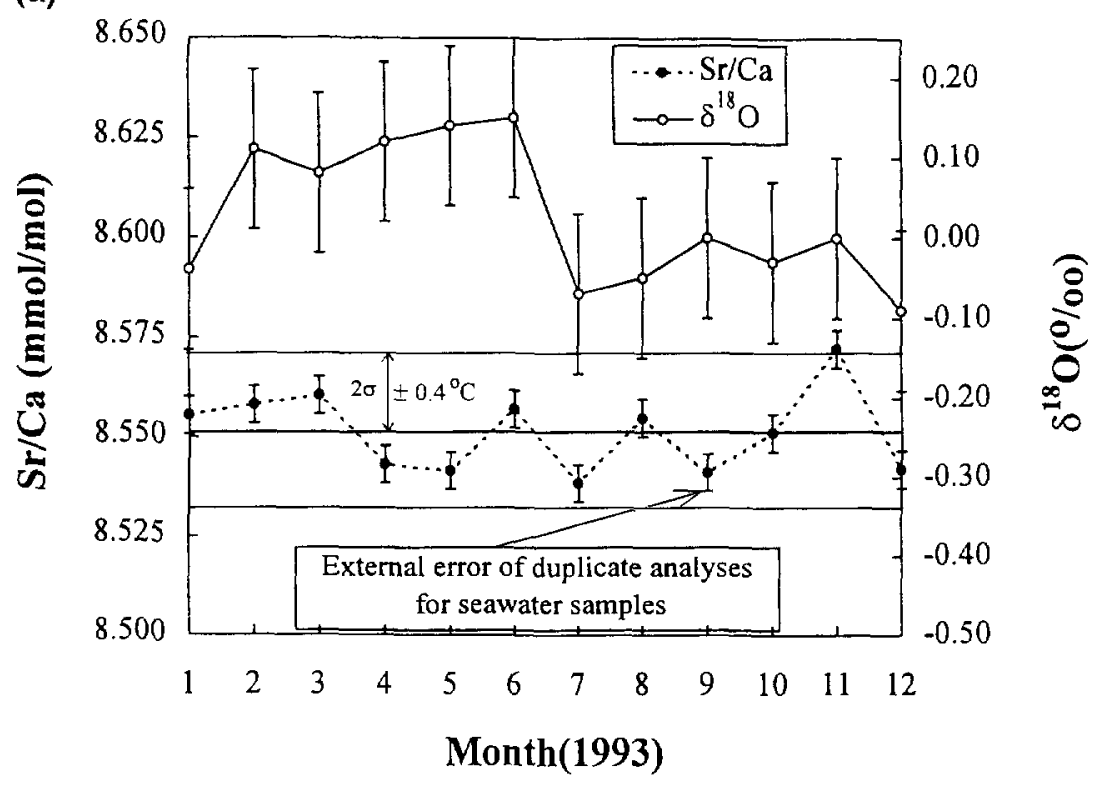

(b)

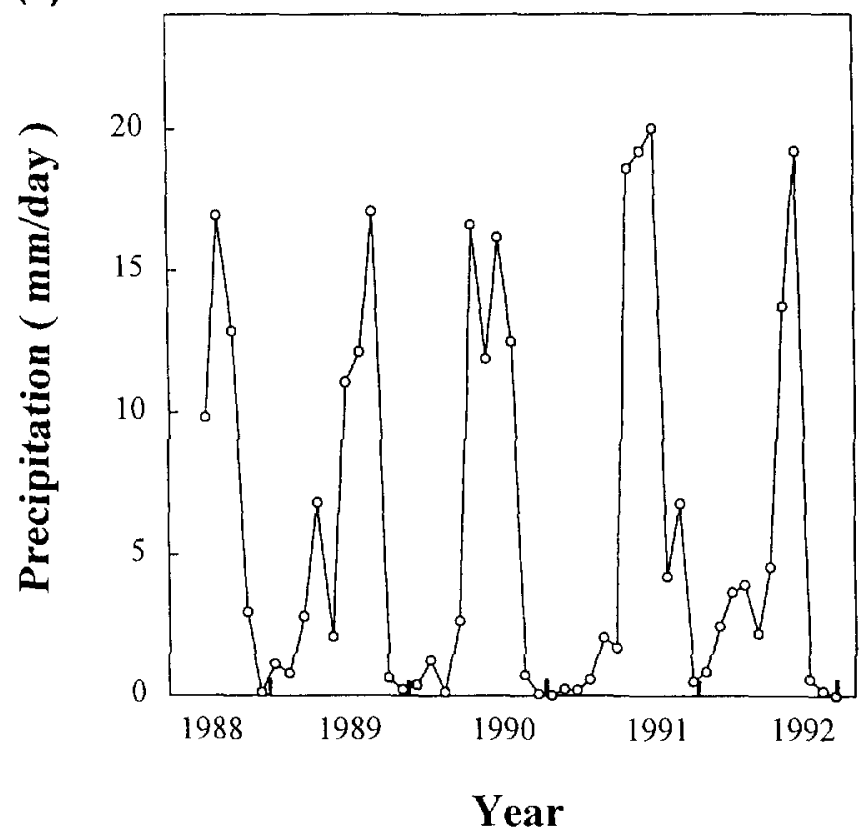

Fig. 5. (a) Annual variation of $\mathrm{Sr} / \mathrm{Ca}$ and $\delta^{18} \mathrm{O}_{\mathrm{PDB}}$ in the sea surface water $(0.45 \mu \mathrm{m}$ filtered) determined by monthly sampling throughout 1993. The variation of $\delta^{18} \mathrm{O}_{\mathrm{PDB}}$ depends on rainfall. Summer (wet season) $\delta^{18} \mathrm{O}_{\mathrm{PDB}}$ in the sea surface water is $\sim 0.18 \%$ lighter than that in winter. The ratio of $\mathrm{Sr} / \mathrm{Ca}$ varies less systematically and was possibly influenced more by the oceanic current. The mean of annual $\mathrm{Sr} / \mathrm{Ca}$ ratio was $8.5514 \mathrm{mmol} / \mathrm{mol}$. The 2 $\times$ S.D. is $\pm 0.0204 \mathrm{mmol} / \mathrm{mol}$ which corresponds to $\pm 0.4^{\circ} \mathrm{C}$ in SST. (b) The monthly precipitation data from $1988-$ 1992. Note that the rainfall in Kenting concentrates in the summer months. Also note that the summer of 1991 saw the most intense precipitation thus fresh water input. (c) Comparison between $\mathrm{Sr} / \mathrm{Ca}$ ratio and $\delta^{18} \mathrm{O}_{\mathrm{PDB}}$ of $P$. lutea, there was an apparent $\delta^{18} \mathrm{O}$ anomaly with a decrease of $0.4 \%$ in the summer of 1991 possibly caused by the large freshwater input.

own inherent $\mathrm{Sr} / \mathrm{Ca}$ ratios (dVSN), we first note that the mean $\mathrm{Sr} / \mathrm{Ca}$ ratio of sea surface water in Nanwan Bay, 8.551 $\mathrm{mmol} / \mathrm{mol}$, is higher than that in the Hawaiian Islands, 8.510 $\mathrm{mmol} / \mathrm{mol}$ by a difference of $0.041 \mathrm{mmol} / \mathrm{mol}$, corresponding to about $0.7^{\circ} \mathrm{C}$ in temperature difference. The effect can be corrected by subtracting off the sea water differences, and

$$
\begin{aligned}
& \mathrm{Sr} / \mathrm{Ca}_{\mathrm{N}}=10.266-0.0505 \times \mathrm{SST} \text { for } P . \text { lutea, } \\
& \mathrm{Sr} / \mathrm{Ca}_{\mathrm{N}}=10.315-0.0528 \times \mathrm{SST} \text { for } P . \text { lobata, }
\end{aligned}
$$


(c)

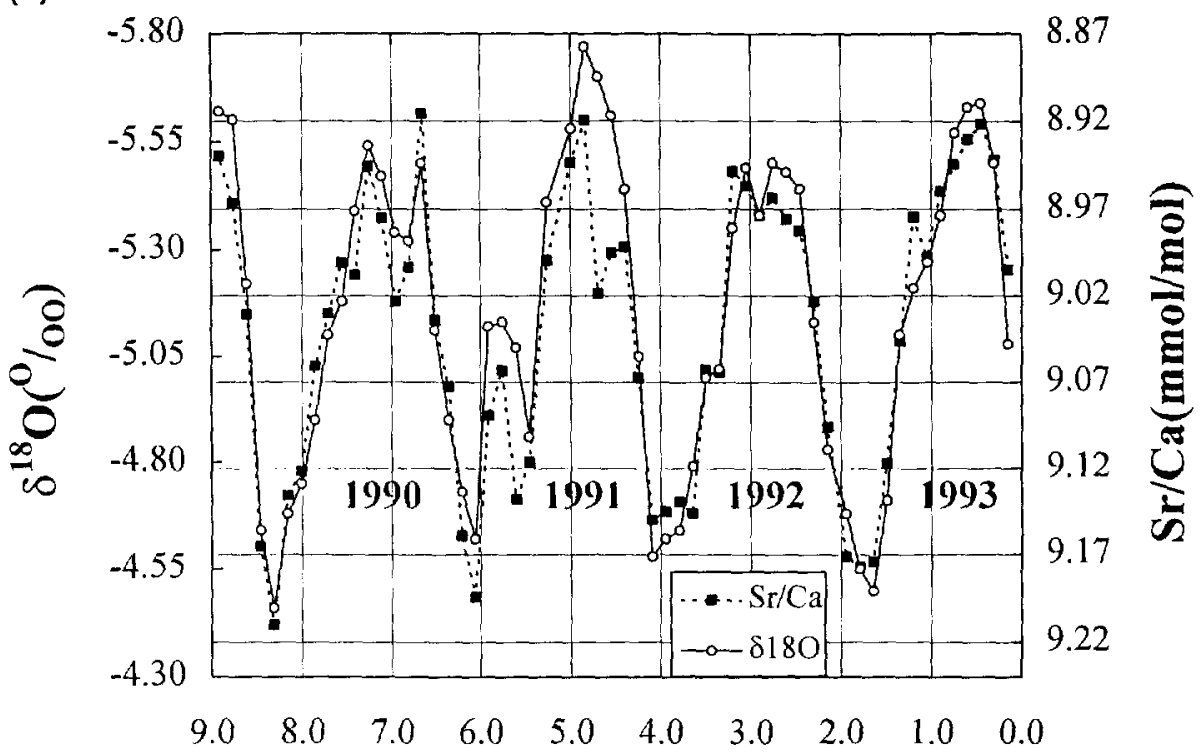

\section{Distance to Top (cm)}

FIG. 5. (Continued)

where $\mathrm{Sr} / \mathrm{Ca}_{\mathrm{N}}$ is the corrected coral $\mathrm{Sr} / \mathrm{Ca}$ ratio normalized to the $\mathrm{Sr} / \mathrm{Ca}$ ratio of sea surface water in the Hawaiian Islands ( dVSN) by taking off the discrepancy of $\mathrm{Sr} / \mathrm{Ca}$ ratio between different sea surface waters and defined as

$$
\mathrm{Sr} / \mathrm{Ca}_{\mathrm{N}} \equiv \mathrm{Sr} / \mathrm{Ca}_{\text {coral }}-\left[\mathrm{Sr} / \mathrm{Ca}_{\text {seawater }}-8.510\right] \text {. }
$$

In Eqn. 5, $\mathrm{Sr} / \mathrm{Ca}_{\text {seawater }}$ is the $\mathrm{Sr} / \mathrm{Ca}$ ratio of sea surface water of the sampling site and the unit is $\mathrm{mmol} / \mathrm{mol}$. The mean $\mathrm{Sr} / \mathrm{Ca}$ value for two seawater samples from the coral sampling site in New Caledonia of Beck et al. (1992) was 8.4641 $\mathrm{mmol} / \mathrm{mol}$ (Beck, 1995, pers. commun.). So, we can normal-

Table 2. Sea water $\mathrm{Sr} / \mathrm{Ca}$ and $\delta^{18} \mathrm{O}_{\mathrm{PDB}}$ of Nanwan sampling site. ${ }^{a}$

\begin{tabular}{cccc}
\hline Date & Month & $\delta^{18} \mathrm{O}(\%)$ & $\mathrm{Sr} / \mathrm{Ca}(\mathrm{mmol} / \mathrm{mol})$ \\
\hline $1 / 3 / 93$ & 1 & -0.04 & 8.5549 \\
$2 / 5 / 93$ & 2 & 0.11 & 8.5581 \\
$3 / 6 / 93$ & 3 & 0.08 & 8.5606 \\
$3 / 31 / 93$ & 4 & 0.12 & 8.5432 \\
$5 / 1 / 93$ & 5 & 0.14 & 8.5416 \\
$6 / 5 / 93$ & 6 & 0.15 & 8.5571 \\
$7 / 3 / 93$ & 7 & -0.07 & 8.5385 \\
$7 / 31 / 93$ & 8 & -0.05 & 8.5550 \\
$8 / 31 / 93$ & 9 & 0.00 & 8.5413 \\
$9 / 28 / 93$ & 10 & -0.03 & 8.5513 \\
$11 / 6 / 93$ & 11 & 0.00 & 8.5723 \\
$12 / 10 / 93$ & 12 & -0.09 & 8.5421 \\
\hline & Max. & 0.15 & 8.5723 \\
& Min. & -0.09 & 8.5385 \\
& Mean & 0.03 & 8.5514 \\
& $2 \times$ S.D. & 0.17 & 0.0204 \\
\hline
\end{tabular}

a. All water samples were filtered using $0.45 \mu \mathrm{m}$ membranes ize their $\mathrm{Sr} / \mathrm{Ca}$ to the Hawaii seawater also. The resulting three $\mathrm{Sr} / \mathrm{Ca}$-SST lines overlap much better after this normalization (Fig. 7a). Therefore, when the $\mathrm{Sr} / \mathrm{Ca}$ ratios of local seawater and of coral skeleton are known, SST can be calculated (assuming a Hawaiian sea surface water $\mathrm{Sr} / \mathrm{Ca}$ value of $8.510 \mathrm{mmol} / \mathrm{mol}$ ) from

$$
\begin{aligned}
\mathrm{SST}=34.77 & +19.80 \\
& \times\left(\mathrm{Sr} / \mathrm{Ca}_{\text {sea }}-\mathrm{Sr} / \mathrm{Ca}_{\text {coral }}\right) \text { for } P . \text { lutea }, \\
\mathrm{SST}=34.19 & +18.94 \\
& \times\left(\mathrm{Sr} / \mathrm{Ca}_{\text {sea }}-\mathrm{Sr} / \mathrm{Ca}_{\text {coral }}\right) \text { for } P . \text { lobata } .
\end{aligned}
$$

An alternative approach to account for the seawater effect is to use the distribution coefficient (Fig. 7b), defined as

$$
D[\mathrm{Sr} / \mathrm{Ca}] \equiv[\mathrm{Sr} / \mathrm{Ca}]_{\text {coral }} /[\mathrm{Sr} / \mathrm{Ca}]_{\text {sea }} \text {. }
$$

The corresponding equations for $D[\mathrm{Sr} / \mathrm{Ca}]$ are $P$. lutea:

$$
D=1.2054-0.005901 \times \mathrm{SST}
$$

P. lobata:

$D=1.2111-0.006179 \times \mathrm{SST}$ (this work)

$D=1.2381-0.007378 \times \mathrm{SST} \quad($ Beck $)$,

$D=1.2875-0.009268 \times \mathrm{SST}(\mathrm{dVSN})$.

When Eqns. 10 and 12 are compared, we found that the two $P$. lobata lines intersect at about $24^{\circ} \mathrm{C}$ which is close to the mean annual SST (Fig. 7b). Therefore, there is little difference when either equations is used for the mean annual SST. However, the slopes of the two equations are quite 
(a)

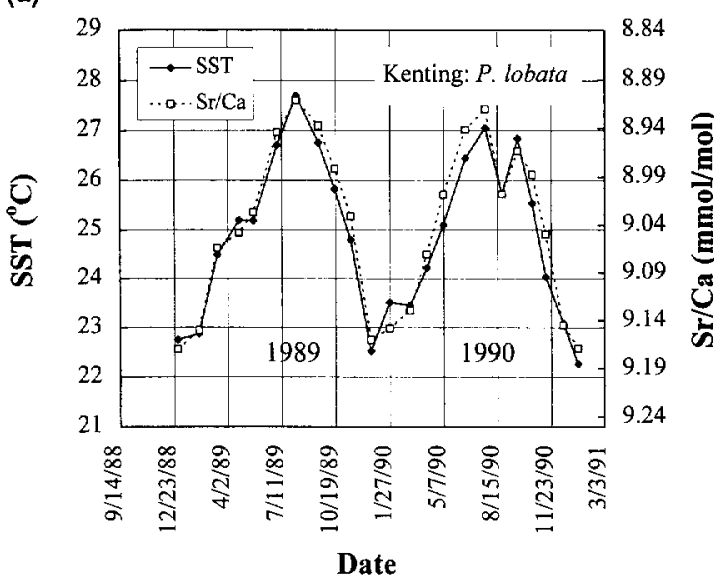

(c)

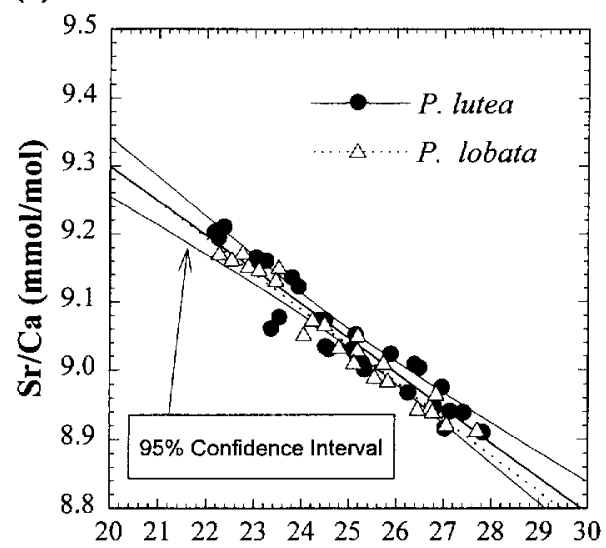

Sea Surface Temperature $\left({ }^{\circ} \mathrm{C}\right)$ (b)

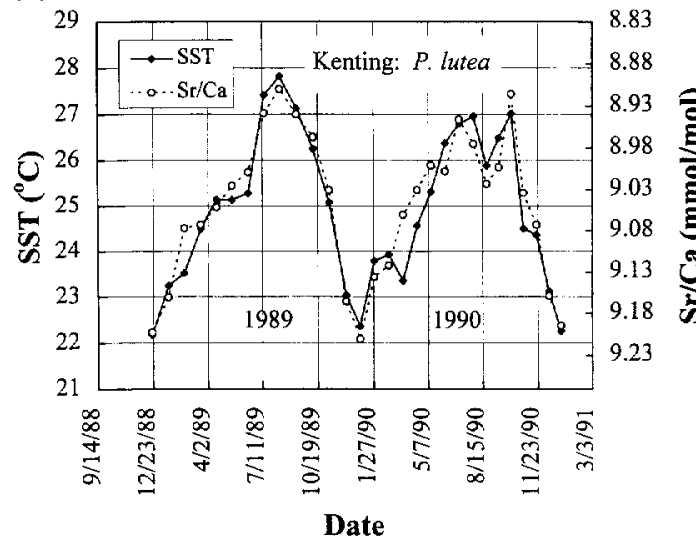

(d)

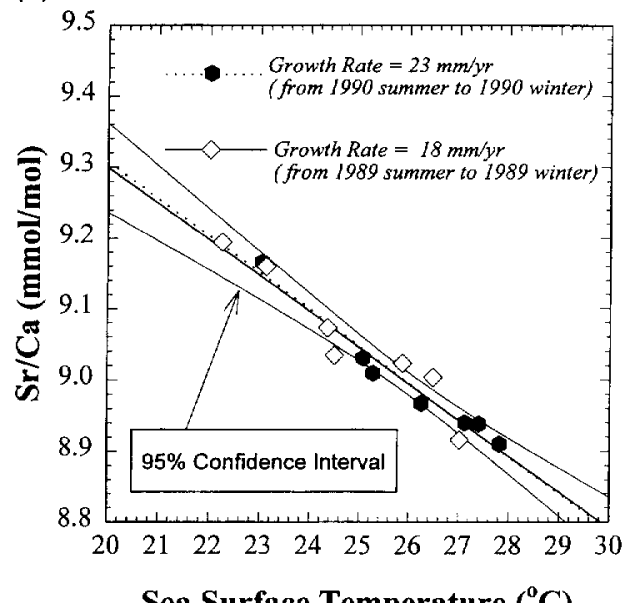

FIG. 6. (a) Comparison between SST and skeletal $\mathrm{Sr} / \mathrm{Ca}$ variations in $P$. lobata from $1988-1991$. We convert the sampling positions to time periods by assuming that the temperature extremes correspond to the extreme $\mathrm{Sr} / \mathrm{Ca}$ ratios. (b) Similar plot for $P$. lutea. (c) Plot of Sr/Ca vs. SST for $P$. lutea and $P$. lobata. The two calibrations agree within respective $95 \%$ error envelopes. For the same $\mathrm{Sr} / \mathrm{Ca}$ ratio, the inferred temperatures are identical in winter and differ by at most $0.2 \sim 0.3^{\circ} \mathrm{C}$ in summer. (d) The growth rate effect on skeletal $\mathrm{Sr} / \mathrm{Ca}$-SST relationship for $P$. lutea. The growth rates were $18 \mathrm{~mm} / \mathrm{yr}$ from July to Dec., 1989 and $23 \mathrm{~mm} / \mathrm{yr}$ from July, 1990 to Jan., 1991. Nevertheless, the slopes of two $\mathrm{Sr} / \mathrm{Ca}-\mathrm{SST}$ relationships are indistinguishable within their respective $95 \%$ confidence intervals.

different. This will lead to a difference of about $+1.2^{\circ} \mathrm{C}$ in summer at $27^{\circ} \mathrm{C}$ and about $-1.2^{\circ} \mathrm{C}$ in winter near $21^{\circ} \mathrm{C}$. Beck's line (Eqn. 11) agrees with that of dVSN's at high temperature while it agrees with ours at low temperature (Fig. 7b).

Since our $D$-SST lines have slopes only $67 \%$ that of dVSN one may wonder whether the smaller amplitudes of our measured $\mathrm{Sr} / \mathrm{Ca}$ variation for the same SST are caused by improper sampling which might have averaged over uneven coral growth horizons. This artifact is unlikely to be the cause of the interlaboratory discrepancy because our $\delta^{18} \mathrm{O}$ sensitivity to SST is $0.19 \% 0 /{ }^{\circ} \mathrm{C}$ for $P$. lobata. This compares favorably with the $0.18-0.21 \% \mathrm{c} /{ }^{\circ} \mathrm{C}$ values reported by McConnaughey (1989) and Gagan et al. (1994). If during our sampling we had inadvertently averaged the coral growth then one would have expected the same decrease in $\delta^{18} \mathrm{O}$ thus a SST sensitivity close to $0.12 \% \circ /{ }^{\circ} \mathrm{C}$. This also does not appear to be a temperature effect as that observed for $\mathrm{U} / \mathrm{Ca}$ vs. SST by Min et al. (1995) for Tahiti $\left(28-29^{\circ} \mathrm{C}\right.$ ) and New Caledonia $\left(20-27^{\circ} \mathrm{C}\right)$ since the temperature ranges for Kenting, New Caledonia, and Hawaii used in the three studies were: $22-28^{\circ} \mathrm{C}, 20-27^{\circ} \mathrm{C}$, and $23-28^{\circ} \mathrm{C}$, respectively.

\subsection{Application to Previous Work on Great Barrier Reef and New Caledonia Corals}

McCulloch et al. (1994a) studied the $\mathrm{Sr} / \mathrm{Ca}$ coral record for the Great Barrier Reef of Australia and found a clear signal of the 1982-1983 El Niño. In Fig. 8a we plot their SST inferred using Sr/Ca and dVSN's calibration. For 1978 and 1979 , we also recalculated the SST using our calibration. This leads to an upward revision of the summer temperature maximum from $27^{\circ} \mathrm{C}$ to about $29^{\circ} \mathrm{C}$. The revised SST seems 
(a)

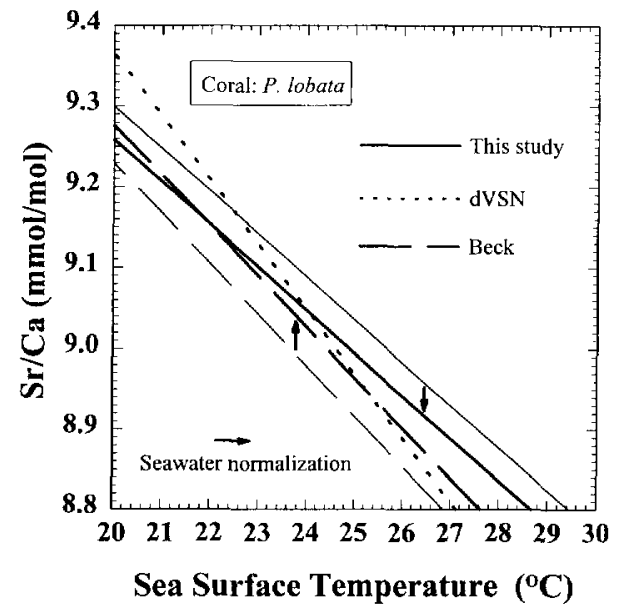

(b)

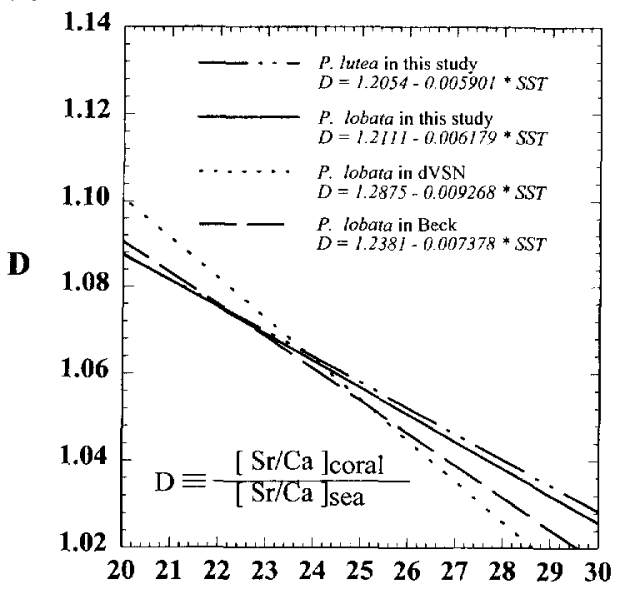

Sea Surface Temperature $\left({ }^{\circ} \mathrm{C}\right)$

FIG. 7. (a) Comparison between $\mathrm{Sr} / \mathrm{Ca}-\mathrm{SST}$ relationships established by Beck et al. (1994), dVSN, and ours. There are serious inconsistencies between these relationships, partly caused by the difference in the $\mathrm{Sr} / \mathrm{Ca}$ ratios of the sea surface waters at different sites. Normalizing the seawater $\mathrm{Sr} / \mathrm{Ca}$ to that of Hawaii would shift our calibration line and Beck's line towards the dVSN line thus reducing the differences. Note the SST used by Beck et al. (1992, 1994) was inferred from oxygen isotope data indirectly. (b) The corresponding $\mathrm{D}[\mathrm{Sr} / \mathrm{Ca}]-\mathrm{SST}$ relationships.

to agree better with the mean summer maximum temperature of $28.8^{\circ} \mathrm{C}$ estimated from direct measurements made at nearby stations over 1975-1978 (Gagan et al., 1994). The shift is owing to mostly the difference between our calibrations and dVSN, not intragenus differences. Similarly, we also note that the SST inferred using the indirect $\delta^{18} \mathrm{O}-\mathrm{Sr} /$ Ca calibration of Beck et al. $(1992,1994)$ by Min et al. (1995) were lower than the actual measured SST (Fig. 8b). Although the inferred SST is coincident with the actual measured SST in winter, there is a discrepancy about $1-2^{\circ} \mathrm{C}$ in summer. Using the $\mathrm{Sr} / \mathrm{Ca}$ ratio of $8.464 \mathrm{mmol} / \mathrm{mol}$ for their seawater (Beck, 1995, pers. commun.), we can reconstruct the SST by our new calibration (Eqn. 7 or Eqn. 10). The discrepancy in summer using Beck's thermometry is reduced to half the original size. These two applications of our calibration seem to support its validity.

\section{CONCLUSIONS}

We have confirmed that potentially paleo-SST can be inferred from coral $[\mathrm{Sr} / \mathrm{Ca}]$ with an accuracy better than $\pm 0.2^{\circ} \mathrm{C}$.

(a)

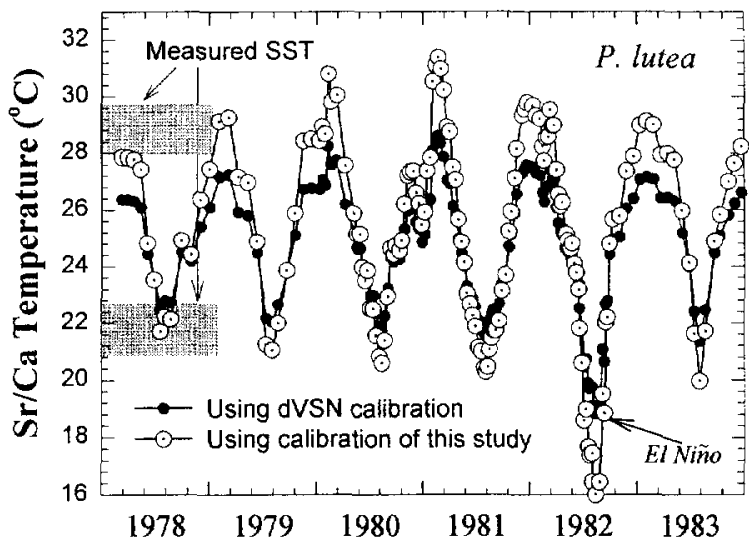

(b)

New Caledonia ( Min et al., 1995)

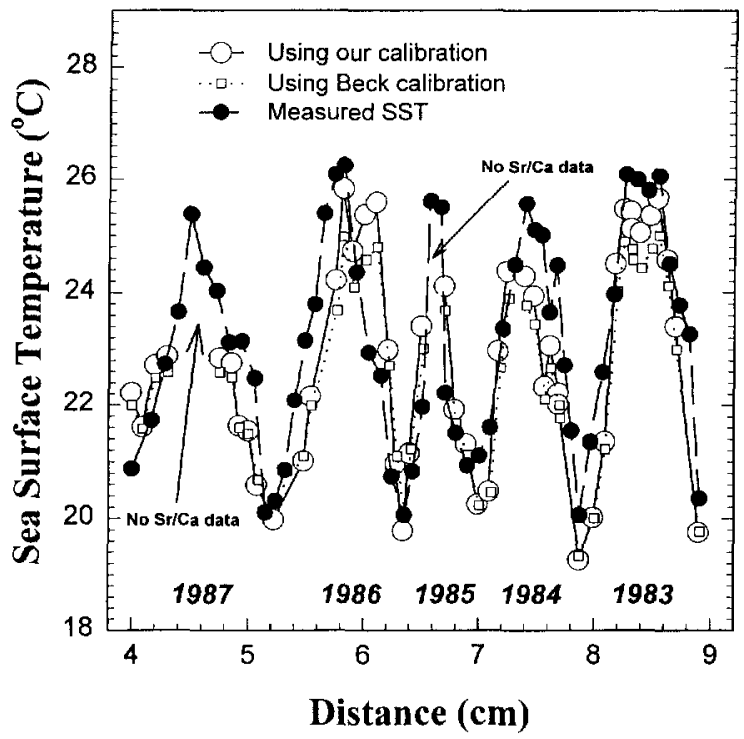

FIG. 8. (a) Application of the new calibration to the Great Barrier Reef. $\mathrm{Sr} / \mathrm{Ca}$ temperature (open circles) was obtained on $P$. lutea but estimated using dVSN's calibration for $P$. lobata by McCulloch et al. (1994a). We have recalculated the temperatures using our calibration for $P$. lutea (open circles). The recalculated temperature agrees better with the range directly measured at a nearby station (shaded bars). (b) Similar plot for New Caledonia corals (Min et al., 1995). They used Beck's Sr/Ca-SST thermometer (1994) to reconstruct the local sea surface temperatures from 1983-1987 (open square). The inferred SST is coincident with the actual measured SST near Amedee Lighthouse, Noumea, New Caledonia ( solid circle) in winter; however, there is a discrepancy about $1 \sim 2^{\circ} \mathrm{C}$ in summer. If our new calibration is applied (open circle) then the discrepancy would be reduced by half 
We have devised a micro-surgical method to sample coral with a resolution better than $0.15 \mathrm{~mm}$, corresponding to less than one week in growth time.

Using a continuous temperature record, we have calibrated the $D[\mathrm{Sr} / \mathrm{Ca}]-\mathrm{SST}$ relations for both $P$. lobata and $P$. lutea. These two relations are identical within errors thus suggesting that there is no intragenus effect between the two species. Pooling their data together and fitting a linear relation, we recommend a single SST calibration for the $\mathrm{Sr} / \mathrm{Ca}$ thermometer on coral Porites:

$$
\mathrm{Sr} / \mathrm{Ca}_{\mathrm{N}}=10.286-0.0514 \times \mathrm{SST}
$$

(N: normalized to Hawaii seawater $\mathrm{Sr} / \mathrm{Ca}$

$$
=8.510 \mathrm{mmol} / \mathrm{mol} \text { ) }
$$

$$
D=1.2077-0.006011 \times \text { SST. }
$$

The calibrations established using $P$. lobata and $P$. lutea growing at rates between 15 and $23 \mathrm{~mm} / \mathrm{yr}$ are identical within respective errors and there exists little growth rate effect for the calibrations.

Comparing the dVSN's calibration on P. lobata with ours, we found a difference of up to $1.2^{\circ} \mathrm{C}$ between $21-27^{\circ} \mathrm{C}$. Therefore, this inter-laboratory difference needs to be resolved. Another calibration, obtained somewhat indirectly by Beck et al. (1992, 1994, and pers. commun.), lies between the two direct calibrations.

Seawater sampled at monthly intervals over 1993 show a range of $[\mathrm{Sr} / \mathrm{Ca}$ ] of $0.033 \mathrm{mmol} / \mathrm{mol}$ equivalent to a temperature uncertainty of $\pm 0.7^{\circ} \mathrm{C}$. Thus the variability of seawater [ $\mathrm{Sr} / \mathrm{Ca}]$ may limit the accuracy of the new thermometry thus needs to be investigated.

Acknowledgments-Dr. Chang Hwa ("China") Chen of this institute kindly transferred his micro-sampling technology for igneous mineral grains to our coral sampling. Ms. Shu-Feng Wu and PeiShan Tsai of this institute graciously helped with the oxygen and carbon isotopic analyses. Mr. Hsin-Wei Chen of this institute generously aided our field work. Mr. Jer-Feng Chang of the Third Nuclear Power Plant kindly provided SST data. We are also grateful to Mr. Deng-Song Chen of the Institute of Oceanography, National Taiwan University, for his assistance with underwater corals sampling. Constructive and comprehensive reviews by $\mathrm{T}$. M. McConnaughey and J. W. Beck significantly improved the paper. Comments on the possible averaging effect of our micro-sampling methods by Professor R. Fairbanks of the Lamont-Doherty Earth Observatory of Columbia University were useful. This research was supported in part by a grant (NSC84-2111-M-001-027 GP) from the National Science Council of the Republic of China. This is contribution IESEP96014 of the Institute of Earth Sciences, Academia Sinica, Taipei.

Editorial handling: R. A. Schmitt

\section{REFERENCES}

Baskaran M. and Santschi P. H. (1993) The role of particles and colloids in the transport of radionuclides in coastal environments of Texas. Mar. Chem. 43, 95-114.
Beck J. W. et al. ( 1992) Sea-surface temperature from coral skeletal Strontium/Calcium ratios. Science 257, 644-647.

Beck J. W. et al. (1994) Errata to Beck et al. (1992). Science 264, 891.

Dai M. H., Martin J. M., and Cauwet G. ( 1995) The significant role of colloids in the transport and transformation of organic carbon and associated trace metals $(\mathrm{Cd}, \mathrm{Cu}$, and $\mathrm{Ni}$ ) in the Rhone delta (France). Mar. Chem. 51, 159-175.

de Villiers S., Shen G. T., and Nelson B. K. (1994) (abbreviated as dVSN) Sr/Ca thermometry in corals: Method calibration and evaluation of $(\mathrm{Sr} / \mathrm{Ca})_{\text {seawater }}$ and interspecies variability. Geochim. Cosmochim. Acta 58, 197-208.

de Villiers S., Nelson B. K., and Chivas A. R. (1995) Biological controls on coral $\mathrm{Sr} / \mathrm{Ca}$ and $\delta^{18} \mathrm{O}$ recontructions of sea surface temperatures. Science 269, 1247-1249.

Draper N. R. and Smith H. (1980) Applied Regression Analysis. 2nd ed., Wiley.

Gagan M. K., Chivas A. R., and Isdale P. J. ( 1994) High-resolution climate records from corals using ocean temperature and massspawning chronometers. Earth Planet. Sci. Lett. 121, 549-558.

Goldberg E. D., Backer M., and Fox D. L. (1952) Microfiltration in oceanographic research. J. Mar. Res. 11, 194-204.

Guilderson T. P., Fairbanks R. G., and Rubenstone J. L. (1994) Tropical temperature variations since 20,000 years ago: Modulating interhemispheric climate change. Science 263, 663-665.

Kinsman D. J. and Holland H. D. (1969) The coprecipitation of cations with $\mathrm{CaCO}_{3}$-IV. the co-precipitation of $\mathrm{Sr}^{2+}$ with aragonite between $16^{\circ} \mathrm{C}$ and $96^{\circ} \mathrm{C}$. Geochim. Cosmochim. Acta 33, 1-17.

Lee T., Shen C. C., Chen C. Y., Wang C. H., and Dai C. F. (1995) SST-D $[\mathrm{Sr} / \mathrm{Ca}]$ calibration for two Porites coral species with onsite continuous temperature recording and seawater $[\mathrm{Sr} / \mathrm{Ca}] \mathrm{moni}-$ toring. EOS(Trans. Amer. Geophys. Un.) 76, 179-180.

Martin J. M., Dai M. H., and Cauwet G. (1995) Significance of colloids in the biogeochemical cycling of organic carbon and trace metals in a coastal environment example of the Venice Lagoon (Italy). Limnol. Oceanogr. 40, 199-131.

McConnaughey T. A. (1989) ${ }^{13} \mathrm{C}$ and ${ }^{18} \mathrm{O}$ isotopic disequilibria in biological carbonates. I. Patterns. Geochim. Cosmochim. Acta $\mathbf{5 3}$, $151-162$.

McCulloch M. T. Gagan M. K , Mortimer G. E. Chivas A. R., and lsdale P. J. ( 1994a) A high-resolution $\mathrm{Sr} / \mathrm{Ca}$ and $\delta^{18} \mathrm{O}$ coral record from the Great Barrier Reef, Australia, and the 1982-1983 El Niño. Geochim. Cosmochim. Acta 58, 2747-2754.

McCulloch M. T., East T., Mortimer G. E., Li X. H., and Chivas A. R. (1994b) High resolution windows into Holocene-Pleistocene climate: $\mathrm{Sr} / \mathrm{Ca}$ coral records of sea surface temperature from the Huon Peninsula, New Guinea. EOS(Trans. Amer. Geophys. Un.) 75, 333.

Min G. R., Edwards R. L., Taylor F. W., Recy J., Gallup C. D., and Beck J. W. (1995) Annual cycles of U/Ca in coral skeletons and U/Ca thermometry. Geochim. Cosmochim. Acta 59, 2025-2042.

Russell W. A., Papanastassiou D. A., and Tombrello T. A. (1978) Ca isotope fractionation on the Earth and other solar system materials. Geochim. Cosmochim. Acta 42, 1075-1090.

Shaw P. T. (1989) The intrusion of water masses into sea southwest of Taiwan. J. Geophys. Res. 94, 123-128.

Smith S. V., Buddemeier R. W., Redalje R. C., and Houck J. E. (1979) Strontium-Calcium thermometry in coral skeletons. Science 204, 404-407.

Taylor R. B., Branes D. J., and Lough J. M. (1993) Simple models of density band formation in massive corals. J. Exp. Mar. Biol. Ecol. 167, 109-125.

Weber J. N. ( 1973) Incorporation of strontium into reef coral skeletal carbonate. Geochim. Cosmochim. Acta 37, 2173-2190. 